\title{
Sintesis Taganing Adaptif Menggunakan Metode Pitch Shifting by Delay-Line Based untuk Standardisasi Gondang Batak Toba
}

\author{
Pasto Juni Ansen Malau*1, Yohannes Suyanto ${ }^{2}$ \\ ${ }^{1}$ Prodi Elektronika dan Instrumentasi,DIKE, FMIPA UGM,Yogyakarta,Indonesia \\ ${ }^{2}$ Departemen Ilmu Komputer dan Elektronika,FMIPA UGM, Yogyakarta, Indonesia \\ Email: *11 pasto.elisnsugm@gmail.com , ${ }^{2}$ yanto@ugm.ac.id
}

\begin{abstract}
Abstrak
Penelitian ini bertujuan untuk membangkitkan warna suara taganing sintetis dengen metode pitch shifting by delay line based. Metode Pitch Shifting By Delay Line Based dilakukan dengan dua tahap utama yaitu tahap analisis dan tahap sintesis. Inti dari proses analisis adalah pendeteksian nilai frekuensi dasar pada masing-masing gendang taganing dan mengelompokan nilai dasar frekuensi tersebut kedalam nilai frekuensi nada standar pada alat musik keyboard. Hasil dari analisis frekuensi sinyal taganing tersebut digunakan sebagai bahan utama untuk melakukan sintesis nada dengan menggunakan metode pitch shifting by delay line-based.

Hasil dari penelitian ini adalah terbentuknya nada sintesis Taganing dengan kenaikan dan penurunan nada dalam range satu oktaf. Adapun pengujian hasil sintesis menggunakan metode perbandingan dengan nilai frekuensi nada standar pada keyboard. Dari hasil pengujian didapatan nilai persentase ketepatan hasil sintesis dengan nilai rata-rata $98.87 \%$.
\end{abstract}

Kata kunci-Taganing, pitch shifting by delay line based, sintesis nada.

\begin{abstract}
This research using pitch shifting by delay line based method which consist of two main stage. The first stage is called analysis stage (framing, windowing, pre-emphasis and deemphasis and FFT) that can detect the value of fundamental frequency of each taganing's gendang. Then, this fundamental frequncy from each gendang will be classified into keyboard tones. The second one is called synthesis stage that will process the fundamental frequency become a new desire signal by creat an upward pitch change or a downward pitch change by delay line based method.

Result of this research is created new signals as standard tones of each taganing's gendang. The evaluation of synthesis output is using comparation method between fudamnetal frequency value of signal output as result of synthetis stage and the fundamental frequency value of keyboard standard's tone. From the results of the system, it can be concluded that taganing synthesis tone have $98.87 \%$ accuration rate.
\end{abstract}

Keywords - Taganin, pitch shifting by delay line based, synthetics tone 


\section{PENDAHULUAN}

Taganing merupakan salah satu instrumen pukul dari sekian banyak instrumen pukul tradisional Batak Toba. Taganing dimainkan dengan cara dipukul menggunakan palu-palu (stick). Taganing terdiri dari enam buah gendang yang dibuat berbentuk tabung melengkung (barrel) atau tabung lurus (sylindrical). Keenam gendang tersebut memiliki nama masingmasing secara berurutan yaitu Tingting (gendang paling kecil), paidua Tingting, Paitonga, Paidua Odap, Odap, dan Odap-odap (gendang paling besar) [1].

Taganing dibuat secara manual dengan tangan dan pengaturan nada pada instrumen Taganing diatur dengan berdasarkan perasaan dan pengalaman subjektif pengrajin Taganing. Akibatnya, fluktuasi frekuensi dalam sinyal tidak diatur dengan benar. Spektrum frekuensi tiap alat sebuah Taganing bisa tidak sama dari perangkat Taganing yang lainnya, sehingga sulit diwujudkan dua set Taganing yang identik. Untuk mengatasi persoalan tersebut digunakan metode Pitch Shifting dengan memanfaatkan teknik delay line based untuk melakukan standardisasi nada.

Pitch shifting adalah menggeser frekuensi dasar dengan atau tanpa mengubah durasi dari sinyal. Secara umum, pitch shifting dapat dilakukan dalam domain waktu maupun domain frekuensi [2]. Penelitian ini akan menggunakan salah satu teknik pitch shifting dalam domain waktu yaitu delay line-based. Teknik ini dipilih karena mampu melakukan pitch shifting secara cepat tanpa memerlukan proses filtering dan resampling serta menjadi teknik yang ideal untuk modifikasi tone [3].

\section{METODE PENELITIAN}

Penelitian ini menggunakan beberapa peralatan, diantaranya adalah satu set taganing Batak Toba, seperangkat PC, Microphone, external sound card, dan seperangkat software studio one dan Matlab.Pengambilan data dilakukan dengan cara merekam setiap gendang mulai dari odap-odap hingga ting-ting dengan masing-masing lima kali perekaman. Proses perekaman suara dilakukan dengan menggunakan perangkat lunak studio one dengan micropone sebagai sensor suara. Frekuensi cuplikan yang digunakan pada saat perekaman data adalah sebesar $16.000 \mathrm{~Hz}$.

\subsection{Analisis Sistem}

Rancangan sistem dalam penelitian ini adalah rancangan dalam pemrosesan sinyal input yang berupa hasil rekaman taganing yang di set dengan durasi selama satu detik hingga menjadi sinyal output sebagai hasil sintesis. Sistem secara keseluruhan terdiri atas beberapa proses diantaranya adalah proses analisis sinyal untuk menemukan frekuensi dasar nada taganing yang meliputi tahapan framing, windowing, pre-emphasis dan FFT. Kemudian setelah didapatkan frekuensi dasar maka proses selanjutnya adalah melakukan sintesis nada dengan menggunakan metode pitch shifting by delay line based. Berikut merupakan deksripsi sistem secara keseluruhan yang ditunjukkan dengan Gambar 1:

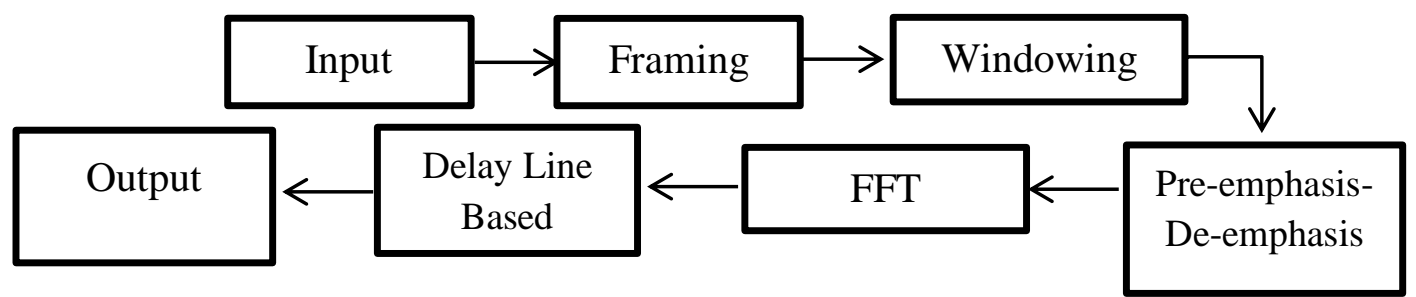

Gambar 1 Deksripsi Sistem secara keseluruhan 
Pengujian hasil sintesis dilakukan dengan menggunaan metode perbandingan. Pengujian dengan metode ini membandingkan nilai frekuensi pergeseran naik-turun nada yang dihasilkan oleh rumus perhitungan frekuensi dengan nilai frequency scaling oleh sistem [4]. Perhitungan frekuensi dapat dirumuskan pada persamaan (1)

$$
\frac{F h}{F l}=2^{n}
$$

dengan fh adalah frekuensi atas, $\mathrm{fl}$ adalah frekuensi bawah dan $\mathrm{n}$ adalah nilai oktaf antara fh dan fl.

Dalam penelitian ini, akan dibandingkan nilai frekuensi hasil output dengan nilai frekuensi standar pada keyboard. Berikut merupakan tabel frekuensi standar pada nada keyboard [5].

Tabel 1 Tabel frekuensi standar pada nada keyboard

\begin{tabular}{|c|c|}
\hline Note & Hz \\
\hline C4 & 262 \\
\hline C\#4 & 277 \\
\hline D4 & 294 \\
\hline D\#4 & 311 \\
\hline E4 & 330 \\
\hline F4 & 349 \\
\hline F\#4 & 370 \\
\hline G4 & 392 \\
\hline G\#4 & 415 \\
\hline A4 & 440 \\
\hline A\#4 & 466 \\
\hline B4 & 494 \\
\hline
\end{tabular}

\subsection{Rancangan Sistem}

\subsubsection{Rancangan Sistem Analisis Sinyal Taganing}

Analisis nada taganing dilakukan untuk mengetahui komponen yang terkandung dalam setiap nada masing-masing taganing. Komponen tersebut akan digunakan sebagai dasar pembentukkan nada sintesis taganing. Analisis yang dilakukan meliputi analisis sinyal pada domain waktu dan analisis sinyal pada domain frekuensi. Rancangan sistem untuk analisis sinyal taganing terdiri atas proses framing, windowing, pre-emphasis dan pendeteksian frekuensi sinyal taganing dengan menggunakan FFT. Berikut akan dijelaskan rancangan sistem analisis sinyal taganing dalam tiap tahapan. 
Pertama adalah proses framing. Pada dasarnya proses framing adalah proses untuk memecah sinyal analog yang telah diubah menjadi sinyal digital ke dalam bentuk frameframe. Proses framing ini dilakukan agar data yang berupa deret dengan panjang tak berhingga dapat dianalisis dengan proses FFT N-point [6]. Dengan memecah data ke dalam frame-frame memungkinkan untuk pembacaan data lebih efektif dan efisien, karena masingmasing frame memiliki informasi yang lebih detail misalnya terkait dengan komponen frekuensi pembentuk sinyal input. Maka rancangan sistem analisis yang pertama adalah dengan mem-frame data hasil rekaman enam gendang taganing.

Proses selanjutnya adalah windowing. Windowing digunakan untuk menghilangkan diskontinuitas yang diakibatkan oleh proses Frame Blocking atau Framing [7] . Pada proses framing data input dipecah dan dibaca untuk diambil informasi pentingnya dari masing-masing frame, maka kemudian dibutukan penggabungan kembali informasi dari masing-masing frame ke dalam bentuk sinyal yang utuh (tidak terpecah-pecah lagi dalam bentuk frame). Pada penelitian ini jenis window yang dipakai adalah jenis Hanning Window dengan pertimbangan hasil windowing lebih halus dalam mengghilangkan efek diskontinuitas. Berikut merupakan persamaan hanning window:

$$
w(n)=0.54-0.46 \cos \left(\frac{2 \pi n}{N}\right)
$$

dengan $\mathrm{w}(\mathrm{n})$ adalah windowing, $\mathrm{N}$ adalah jumlah data dari sinyal dan merupakan waktu diskrit.

Setelah dilakukan proses windowing maka selanjutnya adalah dilakukan proses pre-emphasis dan de-emphasis. Sama halnya dengan proses windowing, tujuan dari pemfilteran ini adalah untuk mendapatkan bentuk spektral frekuensi sinyal yang lebih halus. Filter pre-emphasis didasari oleh hubungan input/output dalam domain waktu yang dinyatakan dalam persamaan sebagai berikut:

$$
\mathrm{y}(\mathrm{n})=\mathrm{x}(\mathrm{n})-\mathrm{ax}(\mathrm{n}-1)
$$

dengan: a merupakan konstanta filter pre-emhasis, biasanya bernilai $0.9<\mathrm{a}<1.0$, dan $\mathrm{x}$ adalah input

Transformasi fourier adalah suatu metode yang sangat efisien untuk menyelesaikan transformasi fourier diskrit yang banyak dipakai untuk keperluan analisa sinyal seperti pemfilteran, analisa korelasi, dan analisa spectrum [8]. Diskrit Fourier Transformasi (DFT) adalah deretan yang terdefinisi pada kawasan frekuensi - diskrit yang merepresentasikan Transformasi Fourier terhadap suatu deretan terhingga (finite duration sequence). DFT berperan penting untuk implementasi algoritma suatu varitas pengolahan sinyal, karena efisien untuk komputasi berbagai aplikasi. Fast Fourier Transformation atau transformasi Fourier cepat [9], merupakan proses lanjutan dari DFT (Diskrit Fourier Transformation). Transformasi Fourier ini dilakukan untuk mentransformaikan sinyal dari domain waktu ke domain frekuensi. Dalam penelitian ini, sinyal yang telah melalui proses framing, windowing dan pre-emphasis ditransformasikan ke dalam domain frekuensi sehingga didapat informasi mengenai nilai frekuensi masing-masing sinyal. Nilai frekuensi tersebut lebih lanjut akan digunakan sebagai acuan untuk membantu pengelompokan nilai frekuensi sampel terhadap nada keyboard yang standar.

\subsubsection{Rancangan Sistem Sintesis Sinyal Taganing}

Untuk melakukan sintesis digunakan Delay line based. Pada dasarnya cara kerja metode delay line based untuk memperoleh sintesis nada dipengaruhi oleh variabel delay dan proses gain dari dua jenis channel buffer yang berbeda. Rumusan yang dipakai oleh Jake Garrison dan Jisso Jun (2015) adalah bahwa proses pitch shifting terjadi karena adanya dua channel buffer yang bekerja secara bersamaan. Diasumsikan bahwa panjang

IJEIS Vol. 10, No. 2, October 2020 : $131-142$ 
buffer line dari masing-masing channel adalah $30 \mathrm{~ms}$ dan gain channel A dimulai pada nilai 1 sementara gain channel B dimulai pada nilai 0. Maka jika nilai gain channel A adalah 1 maka nilai gain channel B adalah 0, dan sebaliknya jika nilai gain channel A adalah 0 maka nilai gain channel $B$ adalah 1 , begitu seterusnya sehingga selalu memenuhi persamaan $\mathrm{Ga}($ gain $A)+\mathrm{Gb}($ gain $B)=1$.

Ketika delay channel A turun dan delay A mendekati nol maka gain A mulai menurun, sementara gain channel B mulai naik. Proses tersebut disebut dengan crossfading. Crossfading dilakukan supaya nilai amplitudo dari sampel yang akan disintesis tetap sama dengan sinyal input. Selain itu, dalam rumusan yang ditawarkan oleh Jake Garrison dan Jisso Jun, crossfading juga membantu perpindahan dari delay $0 \mathrm{~ms}$ menuju delay $30 \mathrm{~ms}$ sehingga sinyal tampak berkelanjutan dan halus. Proses pergantian dari channel satu ke channel lainnya dengan variasi delay secara berkelanjutan dan terus menerus akan menghasilkan hasil atau output pergeseran nada sesuai dengan yang diinginkan.

Berikut merupakan flowchart program pitch shifting by delay line based secara keseluruhan:

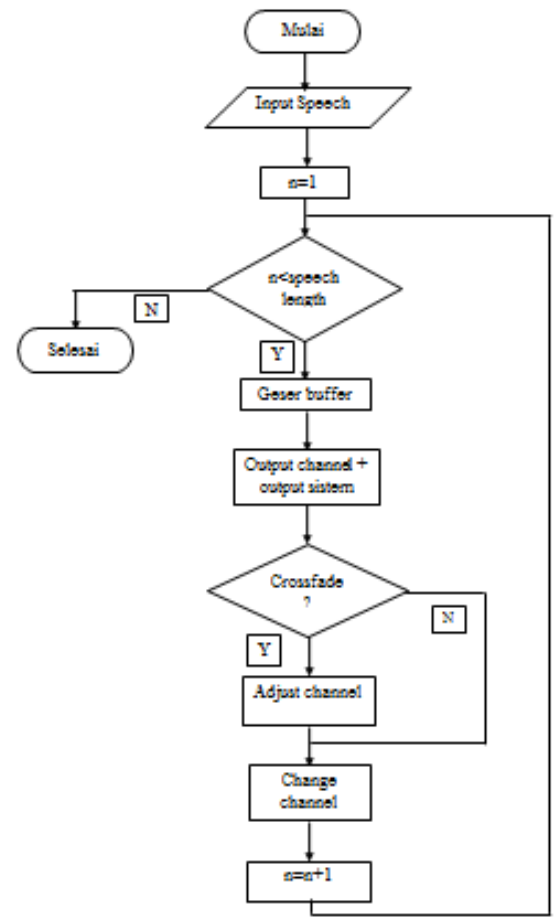

Gambar 2 Flowchart proses pitchshifting by delay line based

\subsection{Implementasi}

\subsubsection{Implementasi Sistem Analisis Sinyal Taganing}

Secara keseluruhan sistem analisis sinyal taganing dilakukan dengan empat tahapan yaitu framing, windowing, pre-emphasis dan analisis frekuensi sinyal input rekaman taganing dengan menggunakan FFT. Keenam data hasil rekaman taganing dengan data cuplikan sebeesar $16.000 \mathrm{~Hz}$ dan durasi rekaman selama satu detik kemudian dianalisis untuk menentuka nilai frekuensi dasar dengan menggunakan FFT melalui tahapan framing, windowing, dan pre-emphasis sebelumnya.

\subsubsection{Implementasi Framing terhadap Data Rekaman Alat Musik Taganing}

Pertama, dalam tahap ini sinyal hasil rekaman alat musik taganing dipecah menjadi beberapa frame atau blok. Hal ini bertujuan untuk melakukan efisiensi terhadap pembacaan 
data input rekaman taganing. Maka rekaman taganing yang telah dibatasi data cuplikannya sebesar $16.000 \mathrm{~Hz}$ pada tahap ini dibagi menjadi beberapa frame. Proses pemecahan data rekaman taganing kedalam bentuk frame-frame dipegaruhi oleh beberapa variabel yaitu time frame steps $\left(\mathrm{t}_{\mathrm{fs}}\right)$ yang menunjukkan berapa lama waktu yang dibutuhkan untuk melakukan perpindahan dari satu frame ke frame yang lain, overlap $\left(\mathrm{t}_{0}\right)$ merupakan waktu yang dibutuhkan untuk memulai frame baru sampai frame yang sedang berlangsung berhenti, dan frame length $\left(\mathrm{t}_{\mathrm{fl}}\right)$ yaitu lebar data per frame. Hubungan beberapa variabel tersebut dapat digambarkan dalam persamaan (4) berikut:

$$
t f l=t f s+\mathrm{t} 0
$$

Adapun untuk mengkonversikan variabel-variabel yang terdapat pada persamaan (4) terhadap sampel dilakukan dengan rumus (5.):

$$
n=t s t . f s
$$

Dengan $\mathrm{n}$ : jumlah sample, $\mathrm{t}_{\mathrm{st}}$ : waktu konstan dan fs : frekuensi sampel

Berikut merupakan cuplikan program untuk mengimplementasikan proses framing pada data sinyal rekaman alat musik taganing yang ditunjukkan dengan Gambar 3:

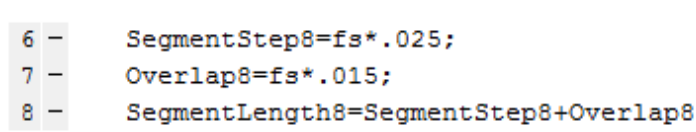

Gambar 3. Cuplikan program untuk implementasi proses framing pada sinyal rekaman alat musik taganing

Program tersebut dimaksudkan untuk membentuk bagian-bagian penting dalam proses framing. SegmentStep 8 ditujukan untuk membentuk 400 sample dari nilai frekuensi sample sebesar $16.000 \mathrm{~Hz}$. Hal ini membutuhkan time frame steps $\left(\mathrm{t}_{\mathrm{fs}}\right)$ sebesar $25 \mathrm{~ms}$. Sementara, Overlap8 ditujukan untuk membentuk 240 sampel dari nilai frekuensi sampel. Hal ini membutuhkan waktu overlap $\left(\mathrm{t}_{0}\right)$ sebesar $15 \mathrm{~ms}$. Dari hasil penjumlahan segment steps8 dan overlap8 maka akan terbentuk segment length8 yaitu sebesar 640 sample sebagai lebar data per frame.

\subsubsection{Implementasi Windowing terhadap Data Rekaman Alat Musik Taganing}

Setelah melakukan proses framing, maka data dibaca kembali secara utuh dan berkesinambungan dengan proses windowing. Proses windowing ini bertujuan untuk mengurangi terjadinya kebocoran spectral atau aliasing yang mana merupakan suatu efek dari timbulnya sinyal baru yang memiliki frekuensi berbeda dengan sinyal aslinya. Efek tersebut dapat terjadi karena rendahnya jumlah sampling rate atau karena proses frame blocking yang menyebabkan sinyal menjadi discontinyu [10]. Berikut merupakan gambaran mengenai implementasi proses windowing dengan menggunakan program pada matlab.

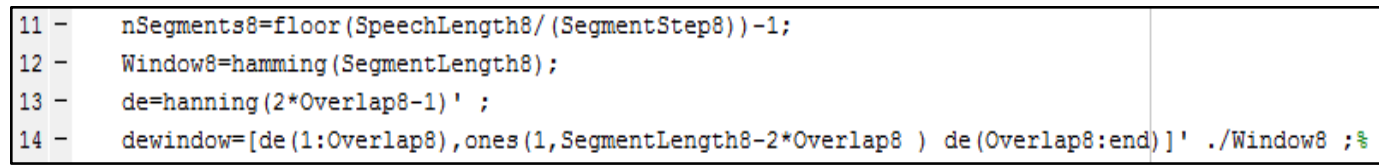

Gambar 4. Implementasi proses windowing pada program matlab

Berdasarkan cuplikan program pada Gambar 4 di atas, nSegments8 digunakan untuk menentukan berapa banyak jumlah steps yang terjadi untuk memproses data, yaitu dengan membagikan lebar data dengan segmen steps. Untuk menjalankan proses window, dipilih dua jenis window yaitu window hanning dan hamming. Window hamming digunakan untuk me-

IJEIS Vol. 10, No. 2, October 2020 : $131-142$ 
windowing tiap frame, window hanning digunakan untuk me-windowing dua kali nilai overlap. Dewindow untuk mengkombinasikan dua window yang digunakan. Penggabungan dua window tersebut akan mengaburkan efek hanning window dan merata-ratakan nilai overlap dari dua frame. Gambar (5), (6) dan (7) berikut menunjukkan hasil proses windowing pada data rekaman taganing:

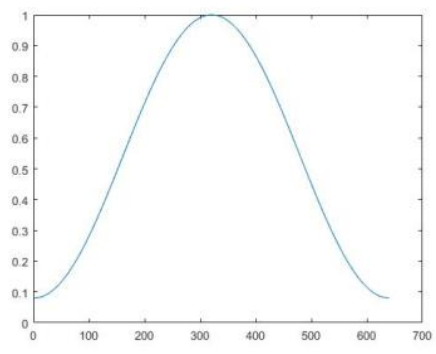

Gambar 5



Gambar 6

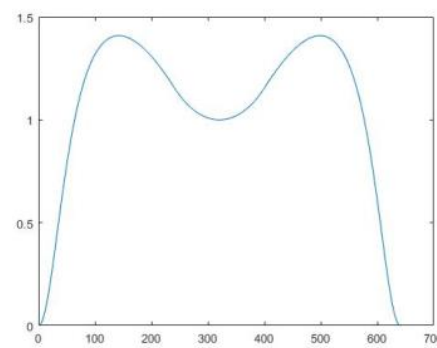

Gambar 7

Gambar 5 menunjukkan penggunaan window hanning pada tiap frame yaitu sebesar 640 sampel, sementara Gambar 6 menunjukkan window hanning untuk mewindow dua kali overlap yaitu senilai 480 sampel, dan Gambar 7 menunjukkan penggabungan kedua window tersebut (dewindow) yang pada akhirnya terbentuk segment length sebesar 640 sampel.

\subsubsection{Implementasi Pre-Emphasis dan De-Emphasis terhadap Data Rekaman Alat Musik} Taganing

Untuk melakukan filter pre-emphasis pada rekaman taganing dapat dilakukan dengan dua cara yaitu filter data keseluruhan secara bersamaan dan filter data perbagian (segmen). Pada penelitian ini implementasi pre-emphasis dilakukan dengan filter data perbagian (segmen) yaitu dengan segmentasi frame sebesar 256. Filter yang digunakan merupakan filter digital, maka fungsi transfernya dituliskan dalam format alihragam $\mathrm{Z}$ dengan rumus:

$$
\mathrm{H}(\mathrm{Z})=1-\alpha \times \mathrm{Z}^{-1}
$$

Maka, formula akhir dari pre-emphasis filter adalah $\mathrm{S}_{2}(\mathrm{n})=\mathrm{s}(\mathrm{n})-\alpha \times \mathrm{s}(\mathrm{n}-1)$.

Seperti yang telah dipaparkan pada rancangan sistem, jika data rekaman taganing telah mengalami pre-emphasis, data tersebut bisa langsung diproses ke tahap selanjutnya. Tetapi sinyal rekaman taganing perlu di-deemphasi terlebih dahulu untuk menggantikan frekuensifrekuensi rendah yang telah dihilangkan pada proses pre-emphasis. Berikut merupakan program yang digunakan untuk menjalankan filter preemphasis dan deemphasis pada rekaman taganing yang ditunjukkan dengan Gambar di bawah:

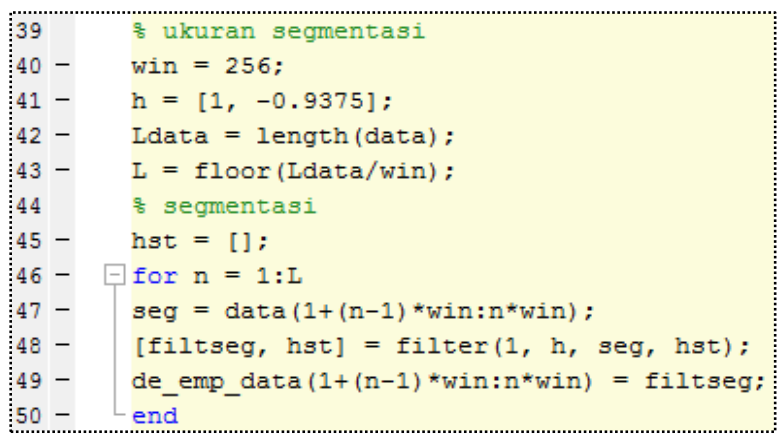

Gambar 8 Cuplikan program untuk menjalankan pre-emphasis 
Catatan: pada cuplikan program di atas, dapat dilihat bahwa penulisan untuk koefisien dari filter adalah $h=[1,-0.9375]$ lalu diikuti dengan fungsi filter sesuai dengan format penulisan.

Hasil eksekusi dari program diatas adalah:

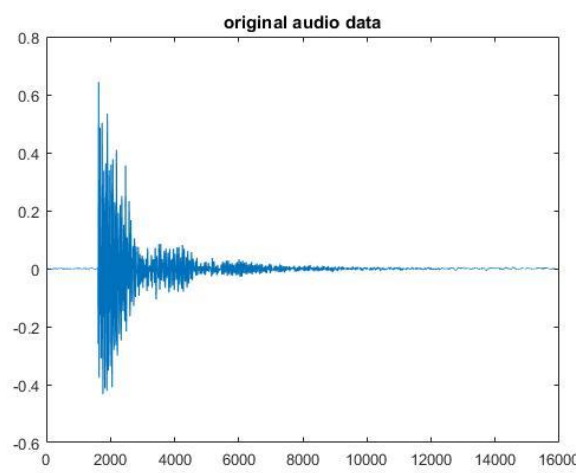

Gambar 9 penampakan sinyal original rekaman taganing gendang kedua dalam domain waktu

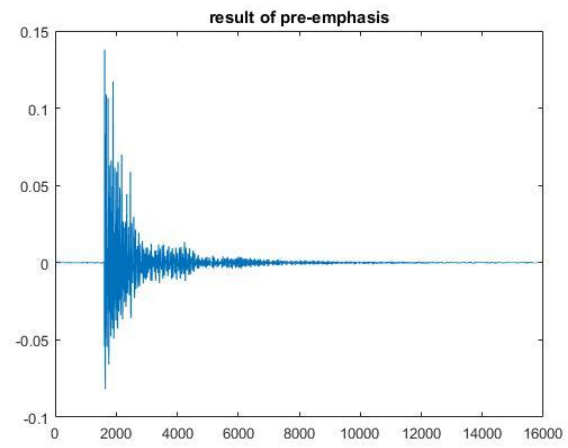

Gambar 11 Sinyal rekaman taganing gendang kedua setelah proses preemphasis dalam domain waktu

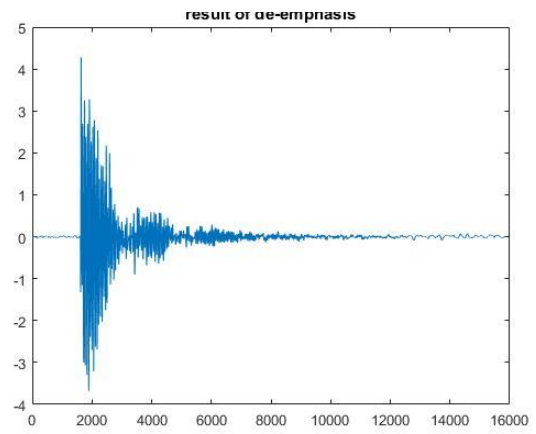

Gambar 13 Sinyal rekaman taganing gendang kedua setelah proses deemphasis dalam domain waktu

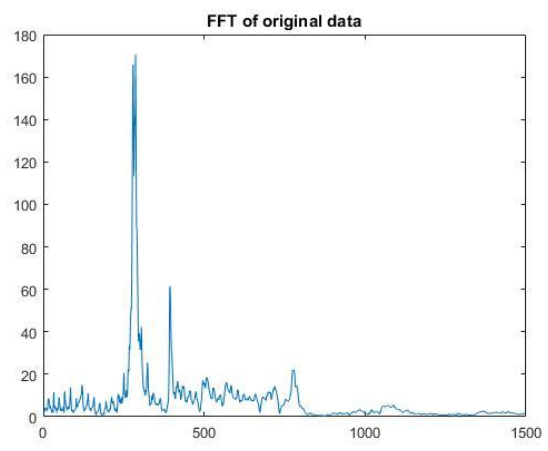

Gambar 10 penampakan sinyal original rekaman taganing gendang kedua dalam domain frekuensi

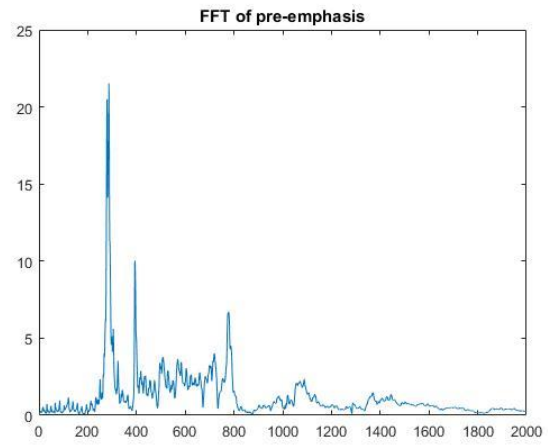

Gambar 12 Sinyal rekaman taganing gendang kedua setelah proses preemphasis dalam domain frekuensi

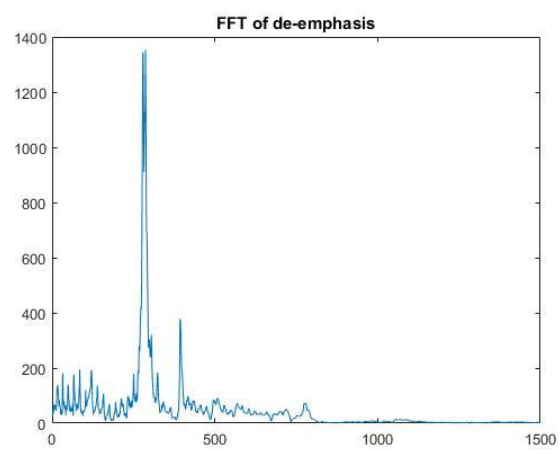

Gambar 14 Sinyal rekaman taganing gendang kedua setelah proses preemphasis dalam domain frekuensi

\section{HASIL DAN PEMBAHASAN}

\subsection{Hasil Analisis Sinyal Suara Taganing}

IJEIS Vol. 10, No. 2, October 2020 : $131-142$ 
Sesuai dengan rencana analisis sinyal suara taganing, dilakukan empat tahap yaitu framing, windowing, pre emphasis dan pendeteksian frekuensi dasar dengan FFT. Analisis tersebut dilakukan pada setiap data rekaman taganing yang telah didapatkan yaitu sebanyak enam data.

Analisis suara taganing dalam domain frekuensi dilakukan dengan menggunakan metode FFT untuk mempilkan sinyal dalam domain frekuensi.

Tabel 2 nilai frekuensi dasar hasil rekaman nada taganing

\begin{tabular}{|l|c|}
\hline \multicolumn{1}{|c|}{ Nama Gendang Taganing } & Nilai Frekuensi Data Rekaman \\
\hline Gendang 1 (Tingting) & $349 \mathrm{~Hz}$ \\
\hline Gendang 2 (Paidua Tingting) & $330 \mathrm{~Hz}$ \\
\hline Gendang 3 (Paitonga) & $310 \mathrm{~Hz}$ \\
\hline Gendang 4 (Paidua Odap) & $294 \mathrm{~Hz}$ \\
\hline Gendang 5 (Odap) & $274 \mathrm{~Hz}$ \\
\hline Gendang 6 (Odap-odap) & $262 \mathrm{~Hz}$ \\
\hline
\end{tabular}

Berdasarkan Tabel 2 diatas dapat diketahui bahwa nilai frekuensi dari data-data pada gendang taganing berbanding lurus dengan urutan taganing. Semakin tinggi nada taganing maka nilai frekuensinya semakin besar.

\subsection{Hasil Sintesis Sinyal Suara Taganing}

Sintesis sinyal suara taganing dilakukan dengan menggunakan metode delay line based, yaitu dengan cara menaikan dan menurunkan frekuensi dasar sinyal taganing hasil rekamann. Masing-masing nada akan dinaikan dan diturunkan untuk membentuk satu oktaf range nada pada keyboard. Misalnya dilakukan kenaikan dan penurunan nada pada gendang ke-lima. Berdasarkan Tabel 2 diketahui nilai frekuensi gendang kelima adalah $274 \mathrm{~Hz}$ yang setara dan atau mendekati kunci C\# pada oktav keempat keyboard. Jika dilakukan kenaikan sebanyak satu semitone ( itch factor $=1.06$ ) dan penurunan nada sebanyak satu semitone ( pitch factor $=0.94$ ) dihasilkan sintesis nada sebagai berikut:

a) Pergeseran kenaikan nada sebesar 1 semitone dari frekuensi dasar gendang kelima dengan nilai frekuensi dasarnya adalah $274 \mathrm{~Hz}$ dan pitch factor sebesar 1.05. Maka pergeseran nadanya adalah $274 \times 1.06=290.44 \mathrm{~Hz}$ (mendekati kunci D pada nada alat musik keyboard).

b) Pergeseran penurunan nada sebesar 1 semitone pada gendang kelima, diketahui nilai frekuensi dasar adalah $274 \mathrm{~Hz}$ dan pitch factor sebesar 0.89. Maka pergeseran nadanya adalah $274 \times 0.94=257 \mathrm{~Hz}$ (mendekati kunci $\mathrm{C}$ pada nada alat musik keyboard).

Berikut merupakan gambar hasil FFT sebelum ( Gambar 15) dan sesudah dilakukan kenaikan (Gambar 16) dan penurunan (Gambar 17) nada :

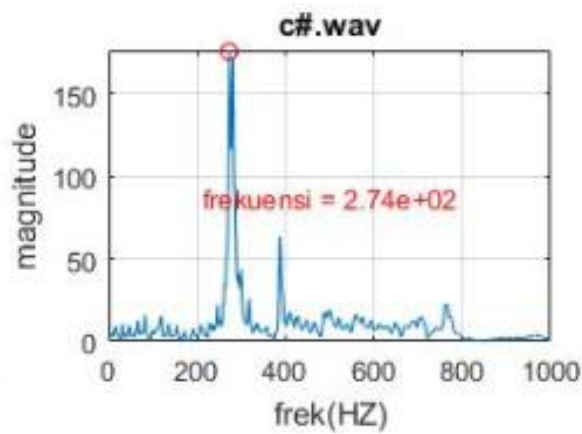

Gambar 15

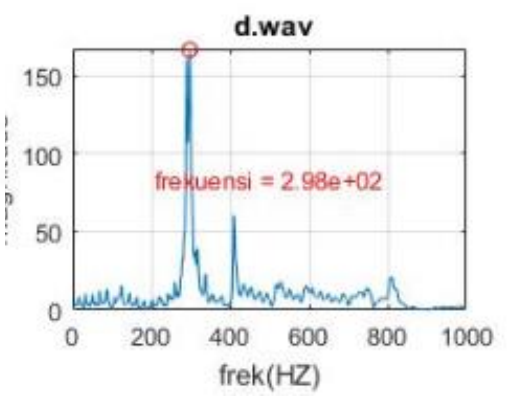

Gambar 16

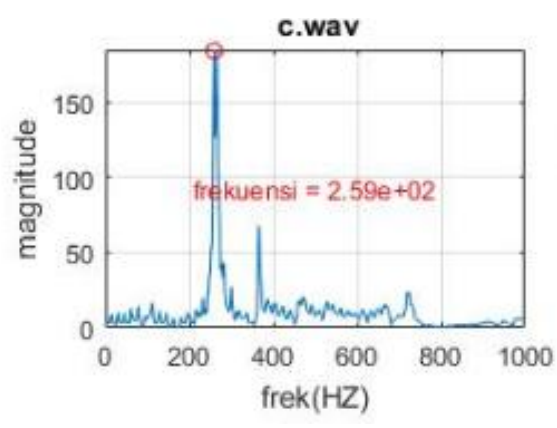

Gambar 17 
Berdasarkan hasil pergeseran nada di atas, dapat disimpulkan bahwa untuk mendaptkan nilai pergeseran nada yang diharapkan akan cukup sulit. Maka dalam penelitian ini hanya untuk verifikasi bahwa nilai pergeseran sudah bekerja terhadap sample yang diambil. Hasil pergeseran hanya mendekati nilai yang diharapkan.

Tabel 3 Hasil Sintesis Nada Taganing

\begin{tabular}{|c|l|l|l|l|l|l|}
\hline & $\begin{array}{c}\text { Gendang } \\
1(\mathrm{~Hz})\end{array}$ & $\begin{array}{l}\text { Gendang } \\
2(\mathrm{~Hz})\end{array}$ & $\begin{array}{c}\text { Gendang } \\
3(\mathrm{~Hz})\end{array}$ & $\begin{array}{c}\text { Gendang } \\
4(\mathrm{~Hz})\end{array}$ & $\begin{array}{c}\text { Gendang } \\
5(\mathrm{~Hz})\end{array}$ & $\begin{array}{c}\text { Gendang } \\
6(\mathrm{~Hz})\end{array}$ \\
\hline C & 265 & 260 & 257 & 464 & 259 & 262 \\
\hline C\# & 280 & 276 & 273 & 278 & 274 & 278 \\
\hline D & 295 & 293 & 292 & 294 & 298 & 296 \\
\hline D\# & 313 & 310 & 310 & 313 & 308 & 315 \\
\hline E & 330 & 330 & 328 & 323 & 335 & 335 \\
\hline F & 349 & 349 & 351 & 340 & 347 & 356 \\
\hline F\# & 369 & 370 & 373 & 360 & 375 & 377 \\
\hline G & 390 & 392 & 397 & 381 & 397 & 401 \\
\hline G\# & 412 & 416 & 422 & 402 & 420 & 425 \\
\hline A & 435 & 441 & 449 & 426 & 438 & 452 \\
\hline A\# & 461 & 468 & 477 & 451 & 464 & 480 \\
\hline B & 487 & 496 & 506 & 477 & 492 & 509 \\
\hline
\end{tabular}

Dari Tabel 3 dapat disimpulan bahwa nada standar hasil rekaman taganing berada pada oktaf keempat frekuensi nada pada keyboard. Maka program delay line based akan menaikan dan menurunkan masing-masing nada untuk membentuk 11 nada lain yang ada pada oktaf keempat frekuensi keyboard.

\subsection{Pengujian Hasil Sintesis Nada Taganing}

Pengujian hasil sintesis dilakukan dengan menggunaan metode perbandingan. Pengujian dengan metode ini membandingkan nilai frekuensi pergeseran naik-turun nada yang dihasilkan oleh rumus perhitungan frekuensi dengan nilai frequency scaling oleh sistem. Maksudnya, telah dihasilkan sintesis nada taganing (ditunjukkan tabel 3), dan hasil tersebut akan dibandingkan dengan standar nada pada keyboard (ditunjukkan dengan Tabel 1) sehingga didapatkan persentase nilai ketepatan frekuensi hasil pitch shifting. Hal tersebut dapat digambarkan dengan rumus berikut:

$$
q=\frac{f l}{f h} \times 100 \%
$$

Dengan q : presentase nilai ketepatan hasil sintesis, fl : frekuensi lebih rendah, fh: frekuensi yang lebih tinggi dari kedua nilai frekuensi yang akan dicari nilai ketepatnnya. 
Contohnya dalam menentukan nilai ketepatan hasil sintesis pada nada gendang pertama (Tingting). Pada Tabel 3 dapat dilihat bahwa nilai frekuensi dasar Tingting adalah $349 \mathrm{~Hz}$ yang mendekati dan atau setara dengan nada kunci $\mathrm{F}$ pada oktaf keempat alat musik keyboard. Setelah disintesis dengan penurunan dua semitone, maka didapatkan frekuensi baru sebesar 313 $\mathrm{Hz}$ yang setara dan atau mendekati nada kunci D\# pada oktaf yang sama dengan frekuensi dasar. Pada kasus ini, nilai frekuensi hasil sintesis $(313 \mathrm{~Hz})>$ frekuensi standar pada keyboard (311). Maka nilai frekuensi hasil sintesis menjadi penyebut (fh) sedangkan frekuensi standar pada keyboard menjadi pembilang (fl) sehingg didapatkan:

$$
\frac{311}{313} \times 100 \%=99.36 \%
$$

Berdasarkan rumusan tersebut maka masing-masing nada gendang taganing dalam tiap kenaikan dan penurunan dapat dicari nilai ketepatannya. Berikut merupakan tabel yang menunjukkan persentase hasil ketepatan pengujian hasil sintesis nada taganing.

Tabel 4. Persentase ketepatan pengujian hasil sintesis nada taganing

\begin{tabular}{|l|c|c|c|c|c|c|}
\hline & $\begin{array}{c}\text { Gendang } \\
1 \\
(\%)\end{array}$ & $\begin{array}{c}\text { Gendang } \\
2 \\
(\%)\end{array}$ & $\begin{array}{c}\text { Gendang } \\
3 \\
(\%)\end{array}$ & $\begin{array}{c}\text { Gendang } \\
4 \\
(\%)\end{array}$ & $\begin{array}{c}\text { Gendang } \\
5 \\
(\%)\end{array}$ & $\begin{array}{c}\text { Gendang } \\
6 \\
(\%)\end{array}$ \\
\hline C & 98.86 & 99.23 & 98.09 & 99.24 & 98.85 & 100 \\
\hline C\# & 98.92 & 99.63 & 98.55 & 99.64 & 98.91 & 99.64 \\
\hline D & 99.66 & 99.65 & 99.31 & 100 & 98.65 & 99.32 \\
\hline D\# & 99.36 & 99.67 & 99.67 & 99.67 & 99.03 & 98.73 \\
\hline E & 100 & 100 & 99.39 & 99.39 & 98.50 & 98.50 \\
\hline F & 100 & 100 & 99.43 & 97.42 & 99.42 & 98.03 \\
\hline F\# & 99,72 & 100 & 99.19 & 97.29 & 98.66 & 98.24 \\
\hline G & 94,14 & 100 & 98.74 & 97.19 & 98.74 & 97.75 \\
\hline G\# & 99,27 & 99.75 & 98.34 & 96.86 & 98.80 & 97.04 \\
\hline A & 98.86 & 99.77 & 97.99 & 96.81 & 99.54 & 97.34 \\
\hline A\# & 98.92 & 99.57 & 97.69 & 96.78 & 99.57 & 97.08 \\
\hline B & 98.58 & 99.53 & 97.62 & 96.55 & 99.59 & 97.05 \\
\hline Rata2 & $\mathbf{9 8 . 9 4}$ & $\mathbf{9 9 . 3 3}$ & $\mathbf{9 8 . 6 6}$ & $\mathbf{9 8 . 0 7}$ & $\mathbf{9 9 . 0 2}$ & $\mathbf{9 8 . 2 6}$ \\
\hline
\end{tabular}

Maka rata-rata ketepatan pitch shifting seluruh hasil sintesis adalah $98.78 \%$

\section{KESIMPULAN}

Pitch Shifting dengan menggunakan metode delay line based dapat menaikan dan menurunkan nada dengan rata-rata ketepatan hasil sintesis sebesar $98.78 \%$. Sinyal sintesis yang dihasilkan sistem menghasilkan nilai frekuensi yang mirip dengan suara taganing asli. Berdasarkan hasil penelitian, sistem sudah membangkit suara taganing sintesis berdasarkan nada standar pada keyboard.

\section{SARAN}

Dari perhitungan pitch shift rate sistem belum dapat menentukan secara pasti dan tepat terkait nilai pergeseran pitch. Untuk memverifikasi nilai pergeseran nilai pitch dengan menggunakan sistem masih dirasa sulit karena algoritma pendeteksi nada yang digunakan tidak sepenuhnya real, dan nilai pitch shift rate hanya masih merupakan perkiraan dari jumlah pergeseran nada. Maka atas dasar hal tersebut dibutuhkan penelitian lebih lanjut. 


\section{DAFTAR PUSTAKA}

[1] N. Manurung, "Bentuk dan Fungsi Musik Gondang Sabangunan Batak Toba pada Grup Horas Rapolo Musik di Semarang”, Skripsi, Universitas Negeri Semarang, p. 2-3, 2015 [Online]. Available: http://lib.unnes.ac.id/21941/1/2501411046-S.pdf [Accessed: 20 Februari 2017]

[2] J. Garrison and J.Jung, "Pitch Shifter", 2011 [Online]. Available: http://jakegarrison.me/docs/Pitch_Shift_Pres.pdf (Accessed: 20 Februari 2017)

[3] K. Jinho, "Automatic Pitch Detection and Shifting of Musical Tones in Real Time", Thesis, Computer Science Departemen, Boston College, p.31, 2013 [Online]. Available: https://www.bc.edu/content/dam/files/schools/cas_sites/cs/pdf/academics/honors/13kim.pd f [Accessed: 10 Februari 2017]

[4] G.A Prayogo and Y.K Suprapto, "Pergeseran Frekeunsi Dasar Sinyal Gamelan Menggunakan Metode Phase Vocoder", 2014 [Online]. Available: https://anzdoc.com/pergeseran-frekuensi-dasar-sinyal-gamelan-menggunakan-phase-.html [Accessed: 15 Maret 2017]

[5] B. Pono, Kamus Musik.Yogyakarta, Kanisius, 2013

[6] K. Engan, Frame Based Signal Representation and Compression. Norway, Stavanger University College, 2015

[7] Muljono and Hariad, "Sintesis Nada Saron Menggunakan Pitch Shifting Phase Vocoder untuk Standarisasi Suara Saron, 2013 [Online]. Available: http://eprints.dinus.ac.id/13195/1/jurnal 13665.pdf [Accessed: 14 Februari 2017]

[8] A.I Hasan, "Pembangkit Warna Suara Saron Sintesis Berdasarkan Petikan Gitar", 2017 [Online]. Available: http://etd.repository.ugm.ac.id/index.php?mod=penelitian detail\&sub=PenelitianDetail\&a $\mathrm{ct}=v i e w \& t y p=h t m l \& b u k u \_i d=129657 \&$ obyek_id=4 [Accessed: 17 Mei 2018]

[9] P. Duhame and M. Vetterli, Fast Fourier Transforms: A Tutorial Review. Boca Raton, CRC Press LLC, 1999

[10] I. Manggolo, "Perencanaan Perangkat Lunak Sintesis Nada pada Komputer dengan Metode Sintesis Aditif", p.5, 2013 [Online]. Available: https://core.ac.uk/download/files/379/11724817.pdf [Accessed: 7 Maret 2017] 